(C) 2015

\author{
Козельський О. М., здобувач
}

ДУ Інститут сільського господарства степової зони Національної академії аграрних наук України

\title{
ОСОБЛИВОСТІ РОЗВИТКУ РОСЛИН РІЗНИХ СОРТІВ ПШЕНИЦІ ОЗИМОЇ В ОСІННІЙ ПЕРІОД ВЕГЕТАЦІЇ ЗАЛЕЖНО ВІД ПЕРЕДПОСІВНОЇ ОБРОБКИ НАСІННЯ В УМОВАХ ПІВНІЧНОГО СТЕПУ
}

\author{
Рецензент - доктор сільськогосподарських наук О. П. Якунін
}

\begin{abstract}
Передпосівна обробка насіння препаратом «Селест Tоn 312.5 FS», який використовували повною $i$ зменшеною дозою, сумісно з мікродобривом «Реакомплюс-зерно» сприяла більш швидкій появі сходів рослин пшениці озимої. На час припинення осінньої вететаиії максимальні значення коефіцієнта кущзення відмічали саме на цих варіантах досліду. Порівняно з контролем, різниця в кущиистості у сортів Писанка, Скарбниия та Апогей Луганський під час вирощування по чорному пару становила 15,$4 ; 14,8 ; 16,0 \%$, після гороху і соняшника - 17,0; 17,4; 19,6\% та 18,6; 18,6; 19,5\% відповідно. Польова схожість та маса 100 абсолютно сухих рослин також були найвищими на ицих варіантах досліду. В середньому за роки досліджень найвищу врожайність забезпечувала передпосівна обробка насіння протруйником «Селест Топ 312.5 FS» $(1,5 \mathrm{r} / \mathrm{m})$ та мікродобривом «Реаком-плюсзерно». Під час вирощування по чорному пару в сорту Писанка вона становила 6,40 m/2a, в сорту Скарбниия - 6,69 m/za, у сорту Апогей Луганський - 6,20 m/2a. За розмімення вказаних сортів після соняшника та гороху урожайність зерна становила 3,74; 3,50; 3,42 m/га та 4,43; 4,13; 3,94 m/га відповідно.
\end{abstract}

Ключові слова: пшениия озима, попередники, сорти, протруйники, мікродобриво, урожайність.

Постановка проблеми. Пшениця озима - головна культура степової зони України. Важливим елементом технології іiі вирощування є передпосівне протруєння насіннєвого матеріалу, що дає можливість забезпечити достатній захист насіння і рослин від широкого комплексу грибкових хвороб. Протруйники фунгіцидної дії захищають пшеницю озиму тільки від ушкодження грибковими хворобами, але не здатні захистити від шкідників. Тому сільськогосподарські виробники додатково використовують інсектициди, додаючи їх до робочої сумішки під час передпосівного протруєння насіння, або, за умови виникнення такої необхідності, у разі обприскування посівів пшениці під час осінньої вегетації.

Останніми роками розповсюдження набули протруйники комбінованої, інсекто-фунгіцидної дії, які дають змогу протистояти ушкодженню пшениці озимої протягом осіннього періоду веге- тації шкідливою мікофлорою та шкідниками. Розробниками заявлено про рістрегулюючу дію цих протруйників, зокрема про позитивний вплив на енергію проростання зерна, на польову схожість, на зимостійкість рослин тощо. Разом 3 тим, результати досліджень, що підтверджують ефективність даних протруйників, у порівнянні $з$ уже існуючими препаратами $є$ обмеженими. Актуальності набуває проведення досліджень в умовах північного Степу України з порівняння ефективності застосування протруйників фунгіцидної та інсекто-фунгіцидної дії, мікродобрива, їх окремого та сумісного впливу на розвиток рослин сучасних сортів пшениці озимої під час вирощування озимини після різних попередників. До того ж розробники хелатних мікродобрив Реаком стверджують про можливість зменшення дози протруйника на 30 \% у випадку їх сумісного застосування для передпосівної обробки насіннєвого матеріалу.

Аналіз останніх досліджень і публікацій, у яких започатковано розв'язання проблеми. Протруєння насіннєвого матеріалу $є$ важливим агрозаходом, який за рахунок забезпечення захисту насіння та рослин в осінній період вегетації, сприяє зростанню урожайності пшениці озимої, а також впливає на розвиток культури $[11,7,4,1$, 6]. За результатами досліджень деяких вчених сівба не протруєним насінням, навіть за виконання інших агротехнічних прийомів вирощування, може спричинити зниження урожайності зерна пшениці озимої майже на третину [2].

На сучасному етапі розвитку рослинництва широкого розповсюдження набувають мікродобрива - збалансований комплекс мікроелементів. Мікродобрива сприяють кращому проростанню насіння, здійснюють позитивний вплив на стійкість рослин до несприятливих факторів під час вирощування озимини [10]. Про ефективність застосування мікродобрив під час вирощування пшениці озимої по стерньовому попереднику зазначають у своїх роботах інші дослідники, які вказують на можливість використання хелатних мікродобрив як за обробки насіння, так і під час обприскування рослин [5]. 


\section{СТОРІНКА МОЛОДОГО ВЧЕНОГО}

Проведений огляд літературних джерел показав, що вивчення протруйників та мікродобрив на даний час в умовах північного Степу України $\epsilon$ недостатнім. Зокрема, не зустрічається інформація щодо визначення ефективності їх використання під час вирощування сучасних сортів пшениці озимої по різних попередниках.

Метою проведених досліджень була оптимізація технології вирощування пшениці озимої.

Завдання досліджень полягало у визначенні особливостей розвитку рослин різних сортів пшениці озимої в осінній період вегетації залежно від передпосівної обробки насіння та попередників в умовах північного Степу.

Матеріали і методи досліджень. Досліди проводили протягом 2009-2012 pр. у дослідному господарстві «Дніпро» ДУ Інституту сільського господарства степової зони (Дніпропетровська область). Грунти дослідних ділянок - чорноземи звичайні малогумусні слабоеродовані. Вміст гумусу в орному шарі грунту становить $3,1-3,3 \%$, загального азоту $-0,17-0,18 \%$, рухомого фосфору - 125-144 мг/кг, обмінного калію - 69-118 мг/кг абсолютно сухого грунту (за Чириковим). Дослідження проводили у польовому трифакторному досліді, закладеному методом послідовних ділянок систематичним способом. Площа елементарної ділянки $80 \mathrm{~m}^{2}$, облікової - $60 \mathrm{~m}^{2}$. Повторність - триразова. Висівали сорти різного типу інтенсивності: універсального (Писанка), інтенсивного (Скарбниця) та напівінтенсивного (Апогей Луганський). Посіви розміщували по трьох попередниках: по чорному пару, після гороху та соняшника.

Під час проведення досліджень користувалися загальноприйнятими методиками і рекомендаціями $[8,9]$. Збирання врожаю проводили методом суцільного обмолоту облікової ділянки комбайном Sampo-500 (пряме комбайнування) за повної стиглості зерна. Статистичну обробку даних урожайності пшениці озимої проводили на ПК методом дисперсійного аналізу за Б. О. Доспєховим [3].

Технологія вирощування пшениці озимої, крім поставлених на вивчення окремих іiі елементів, була загальноприйнятою для північного Степу України. Для передпосівної обробки насіннєвого матеріалу схема досліду передбачала використання протруйників: фунгіцидної дії - «Вітавакс 200 ФФ» (200 г/л карбоксину + 200 г/л тираму), 3 л/т та інсекто-фунгіцидної - «Селест Топ 312.5 FS» (25 г/л флудиоксонілу, 25 г/л дифеноконазолу, 262,5 г/л тіаметоксаму), 1,5 л/т, а також хелатного мікродобрива «Реаком-плюс-зерно» (рідка композиція макроелементів (NPK) та хелатів мікроелементів: $\mathrm{Zn}, \mathrm{Fe}, \mathrm{Cu}, \mathrm{Mn}, \mathrm{Mo}, \mathrm{B}, \mathrm{Co}), 3$ л/т. Окремі варіанти досліду включали обробку насіння мікродобривом сумісно з протруйником, норма витрати якого становила 70 \% від рекомендованої.

Результати досліджень. Відомо, що нестача вологи в посівному шарі грунту на час сівби пшениці озимої в значній мірі затримує проростання насіння, появу сходів і подальший розвиток рослин. Рівень вологозабезпечення в дослідах визначався попередниками та кількістю опадів і не завжди був сприятливим для своєчасного одержання сходів та подальшої вегетації озимини. Так, зволоження шару грунту $0-10$ см було достатнім для одержання сходів рослин в усі роки проведення досліджень. Найвищими вони були по чорному пару і коливалися від 9,0 мм в 2010 р. до 11,8 мм у 2009 році. Дещо нижчими запаси продуктивної вологи у зазначеному грунтовому горизонті були по попереднику горох i становили в зазначені роки - 6,2 та 9,3 мм відповідно. Під час вирощування пшениці озимої після соняшника зволоженість посівного шару була істотно нижчою, ніж по паровому попереднику. За розмірами показника вона також поступалася варіантам досліду, де посіви озимини розміщували після гороху. Так, мінімальні запаси продуктивної вологи (5,5 мм) відмічали у 2010 р., максимальні по цьому попереднику (8,1 мм) - в умовах 2009 року (табл. 1).

Найвищі середні показники запасів вологи у десятисантиметровому шарі грунту за роки досліджень (10,2 мм) були відмічені за сівби по чорному пару.

\section{1. Запаси продуктивної вологи в шарі трунту 0-10 см на час сівби пиениці озимої, 2009-2011 pp.}

\begin{tabular}{|c|c|c|c|}
\hline \multirow{2}{*}{ Рік } & \multicolumn{3}{|c|}{ Попередники } \\
\cline { 2 - 4 } & чорний пар & горох & соняшник \\
\hline 2009 & 11,8 & 9,3 & 8,1 \\
\hline 2010 & 9,0 & 6,2 & 5,5 \\
\hline 2011 & 9,7 & 7,8 & 6,1 \\
\hline середнє & 10,2 & 7,8 & 6,6 \\
\hline
\end{tabular}




\section{СТОРІНКА МОЛОДОГО ВЧЕНОГО}

По цьому попереднику вони перевищували значення даного показника у посівах, розміщених після гороху та соняшника відповідно на 23,5 та $35,3 \%$.

Різниці у тривалості досходового періоду серед сортів пшениці озимої Писанка, Скарбниця та Апогей Луганський не відмічали.

Встановлено, що на варіантах досліду, де насіння обробляли протруйником «Селест Топ», а також за його обробки сумішкою «Селест Топ» + «Реаком-плюс-зерно», сходи пшениці з’являлись на одну добу раніше. Так, на цих ділянках, у середньому за 2009-2011 рр., під час вирощування по чорному пару досходовий період становив 8 діб, після гороху - 10 діб, після соняшника - 11 діб. Аналогічну тенденцію щодо більш швидкого настання фази сходів у рослин пшениці, відмічали протягом усіх років досліджень.

На інших варіантах досліду період появи сходів у середньому за роки досліджень становив 9, 11 та 12 діб відповідно, за сівби по чорному пару, після гороху та соняшника. У розрізі років більш швидкою появою сходів характеризувались посіви пшениці озимої, яку висівали у 2009 р., що було обумовлено кращим зволоженням посівного шару грунту. Більш тривалим період «сівба сходи» був у 2010 р. і становив: по чорному пару - 9 діб, після гороху та соняшника - 12 та 13 діб відповідно.

Визначення польової схожості дало змогу встановити мінливість значень даного показника залежно від попередників, передпосівної обробки насіння та сорту. Різний рівень зволоження посівного шару грунту, обумовлений попередниками, істотно впливав на польову схожість насіння та, відповідно, на густоту рослин в посівах. Під час вирощування пшениці озимої після соняшника дані показники були найнижчими серед попередників. Так, залежно від обробки насіннєвого матеріалу, польова схожість у сорту Писанка знаходилась у межах 70,4-75,5 \%, у сортів Скарбниця та Апогей Луганський - 68,1-73,9 та 68,0-73,2 \% відповідно. По попереднику горох польова схожість була вищою і становила у сорту Апогей Луганський - 78,0-81,9\%, у сорту Писанка - 81,3-84,6 \%, у сорту Скарбниця 79,0-83,5 \%. Сівба по чорному пару за рахунок наявності більшої кількості доступної рослинам води у посівному шарі грунту забезпечувала формування максимальних значень показника польової схожості. Так, у сортів Писанка, Скарбниця та Апогей Луганський польова схожість насіння становила 89,7-94,0; 90,3-94,2 та 88,092,5 \%, а густота рослин - 404-423, 406-424 та
396-416 шт./м² відповідно. Слід відмітити, що за сівби пшениці озимої по непарових попередниках найвищою польова схожість була у сорту Писанка, по паровому попереднику - у сорту Скарбниця.

Істотний вплив на польову схожість мала передпосівна обробка насіннєвого матеріалу. На контрольному варіанті досліду, який передбачав сівбу необробленим насінням, даний показник по усіх сортах та попередниках був найнижчим. Обробка протруйниками і мікродобривом у разі їх застосування, окремо або у сумішці, сприяла зростанню польової схожості. Так, під час вирощування після соняшника, за рахунок обробки насіння протруйником «Вітавакс 200 ФФ» у сорту Писанка схожість зростала 3 70,4\% (контроль) до 71,3\%, у сорту Скарбниця - 368,1 до $70,5 \%$, в сорту Апогей Луганський - 3 68,0 до 69,9\%, від використання препарату «Селест Топ» - до 74,4; 73,0 та 72,3 \% відповідно. Обробка зерна мікродобривом «Реаком-плюс-зерно», порівняно 3 контролем, забезпечувала підвищення схожості на 0,$6 ; 0,7$ та $0,8 \%$.

За сівби сортів Писанка, Скарбниця та Апогей Луганський після гороху, за рахунок протруєння «Вітаваксом 200 ФФ», польова схожість, порівняно 3 контрольним варіантом, зростала на 1,1; 1,3 та 1,1 \%, препаратом «Селест Топ»- на 2,7; 2,6 та 2,8 \%, мікродобривом - 0,5; 0,2 та 0,7\% відповідно.

Аналогічну тенденцію щодо збільшення польової схожості відмічали на ділянках, розміщених по чорному пару (табл. 2).

Слід зазначити, що серед протруйників, які вивчалися нами в досліді, більш ефективним у підвищенні польової схожості насіння виявився «Селест Топ», що свідчить про відсутність фітотоксичності у даного протруйника. Максимальне зростання вказаного показника відмічали на варіантах, де зазначений препарат застосовували сумісно 3 мікродобривом «Реаком-плюс-зерно». Порівняно 3 контрольним варіантом, у випадку вирощування сортів Писанка, Скарбниця та Апогей Луганський по чорному пару схожість зростала на 4,3; 3,9 та 4,5 \% відповідно. За розміщення посівів після соняшника та гороху польова схожість насіння підвищувалась відповідно на 5,1; 5,8; 5,2 та 3,3; 4,5; 3,9 \%. Зменшення дози протруйника на $30 \%$ у разі сумісного його застосування 3 мікродобривом не спричинило істотного зниження польової схожості, порівняно $з$ варіантами досліду, де доза протруйника була повною. 
СТОРІНКА МОЛОДОГО ВЧЕНОГО

2. Польова схожість та густота рослин різних сортів пшениці озимої залежно від передпосівної обробки насіння та попередників (середнє за 2009-2011 рр.)

\begin{tabular}{|c|c|c|c|c|c|c|}
\hline \multirow{3}{*}{ Обробка насіння } & \multicolumn{6}{|c|}{ Попередники } \\
\hline & \multicolumn{2}{|c|}{ чорний пар } & \multicolumn{2}{|c|}{ горох } & \multicolumn{2}{|c|}{ соняшник } \\
\hline & $\%$ & шт./M $\mathbf{M}^{2}$ & $\%$ & шт./M² & $\%$ & шт./M² \\
\hline \multicolumn{7}{|l|}{ Сорт Писанка } \\
\hline Контроль (без обробки) & 89,7 & 404 & 81,3 & 447 & 70,4 & 385 \\
\hline «Вітавакс 200 ФФ» & 90,2 & 406 & 82,4 & 453 & 71,3 & 392 \\
\hline «Реаком-плюс-зерно» & 90,0 & 405 & 81,8 & 450 & 71,0 & 391 \\
\hline «Вітавакс 200 ФФ» + «Реаком-плюс-зерно» & 92,5 & 416 & 83,5 & 459 & 72,3 & 398 \\
\hline «Вітавакс 200 ФФ» (70 \% норми) + «Реаком-плюс-зерно» & 92,4 & 416 & 83,4 & 459 & 72,2 & 398 \\
\hline «Селест Топ» & 93,0 & 419 & 84,0 & 462 & 74,4 & 409 \\
\hline «Селест Топ»+ «Реаком-плюс-зер & 94,0 & 423 & 84,6 & 465 & 75,5 & 415 \\
\hline «Селест Топ» $(70$ \% норми $)+$ «Реаком-плюс-зерно» & 93,9 & 422 & 84,5 & 465 & 75,4 & 415 \\
\hline \multicolumn{7}{|l|}{ Сорт Скарбниця } \\
\hline Контроль (без обробки) & 90,3 & 406 & 79,0 & 435 & 68,1 & 375 \\
\hline «Вітавакс 200 ФФ» & 92,3 & 415 & 80,3 & 442 & 70,5 & 388 \\
\hline пюс-зерно» & 91,2 & 410 & 79,2 & 436 & 68,8 & 378 \\
\hline «Вітавакс 200 ФФ» + «Реаком-плюс-3 & 93,1 & 419 & 81,0 & 446 & 71,0 & 391 \\
\hline «Вітавакс 200 ФФ» (70 \% норми) + «Реаком-плюс-зерно» & 93,0 & 419 & 80,9 & 445 & 70,9 & 391 \\
\hline «Селест Топ» & 93,2 & 419 & 81,6 & 449 & 73,0 & 402 \\
\hline «Селест Топ» + «Реаком-плюс-зерно» & 94,2 & 424 & 83,5 & 459 & 73,9 & 406 \\
\hline «Селест Топ» (70 \% норми) + «Реаком-плюс-зерно» & 94,1 & 423 & 83,3 & 458 & 73,8 & 406 \\
\hline \multicolumn{7}{|c|}{ Сорт Апогей Луганський } \\
\hline Контроль (без обробки) & 88,0 & 396 & 78,0 & 429 & 68,0 & 374 \\
\hline «Вітавакс $200 \Phi \Phi »$ & 89,2 & 401 & 79,1 & 435 & 69,9 & 384 \\
\hline «Реаком-плюс-зерно» & 88,9 & 400 & 78,7 & 433 & 68,8 & 378 \\
\hline 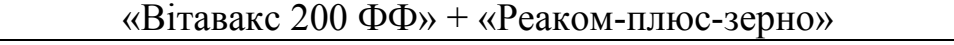 & 91,2 & 410 & 79,8 & 439 & 70,5 & 388 \\
\hline «Вітавакс 200 ФФ» (70 \% норми) + «Реаком-плюс-зе & 91,1 & 410 & 79,7 & 438 & 70,4 & 388 \\
\hline «Селест Топ» & 90,1 & 405 & 80,8 & 444 & 72,3 & 398 \\
\hline «Селест Топ» + «Реаком-плюс-зерно» & 92,5 & 416 & 81,9 & 450 & 73,2 & 403 \\
\hline «Селест Топ» (70 \% норми) + «Реаком-плюс-зерно» & 92,4 & 416 & 81,8 & 450 & 73,1 & 403 \\
\hline
\end{tabular}

\section{3. Умови осіннього періоду вететації пшениці озимої під час її вирощування} по різних попередниках, 2009-2011 pp.

\begin{tabular}{|c|c|c|c|c|}
\hline \multirow{2}{*}{ Показник } & \multirow{2}{*}{ Рік } & \multicolumn{3}{|c|}{ Попередники } \\
\hline & & чорний пар & горох & соняшник \\
\hline \multirow{4}{*}{$\begin{array}{c}\text { Сума опадів за період «сівба - припинення } \\
\text { осінньої вегетації», мм }\end{array}$} & 2009 & 105,0 & 110,0 & 110,0 \\
\hline & 2010 & 127,7 & 137,3 & 137,3 \\
\hline & 2011 & 16,4 & 22,3 & 22,3 \\
\hline & середнє & 83,0 & 89,9 & 89,9 \\
\hline \multirow{4}{*}{$\begin{array}{c}\text { Сума ефективних (вище }+5^{\circ} \mathrm{C} \text { ) температур, } \\
\text { накопичених посівами пшениці озимої } \\
\text { за осінній період, }{ }^{\circ} \mathrm{C}\end{array}$} & 2009 & 284,1 & 369,2 & 369,2 \\
\hline & 2010 & 248,2 & 308,8 & 308,8 \\
\hline & 2011 & 175,8 & 261,2 & 261,2 \\
\hline & відхилення* & $+48,0$ & $+32,1$ & $+32,1$ \\
\hline \multirow{4}{*}{$\begin{array}{c}\text { Тривалість періоду осінньої } \\
\text { вегетації, діб }\end{array}$} & 2009 & 68 & 78 & 78 \\
\hline & 2010 & 73 & 83 & 83 \\
\hline & 2011 & 42 & 52 & 52 \\
\hline & середнє & 61 & 71 & 71 \\
\hline \multirow{3}{*}{ Дата припинення осінньої вегетації } & 2009 & \multicolumn{3}{|c|}{2 грудня } \\
\hline & 2010 & \multirow{2}{*}{\multicolumn{3}{|c|}{2 грудня }} \\
\hline & 2011 & & & \\
\hline
\end{tabular}

Примітка: * - відхилення показника від середньобагаторічної норми 


\section{СТОРІНКА МОЛОДОГО ВЧЕНОГО}

Найбільшу суму опадів за період від сівби до припинення рослинами осінньої вегетації відмічали у 2010 р., яка становила по чорному пару 127,7 мм, після гороху та соняшника - 137,3 мм. Мінімальною вона була у 2011 р. - 16,4 та 22,3 мм відповідно, що обумовлено також менш тривалим періодом осінньої вегетації. В умовах цього року він становив після непарових попередників 52 доби, по чорному пару - 42 доби (табл. 3). Сума ефективних (вище $+5{ }^{\circ} \mathrm{C}$ ) температур, накопичених посівами пшениці озимої за період осінньої вегетації в середньому за 2009-2011 рр. перевищувала середньобагаторічну норму по чорному пару на $48,0^{\circ} \mathrm{C}$, після гороху та соняшника - на $32,1^{\circ} \mathrm{C}$. Мінімальну суму температур озимина накопичувала у 2011 р., максимальну - у 2009 році.

Тривалість періодів розвитку озимини в осінній період вегетації у значній мірі залежала від попередника та передпосівної обробки насіннєвого матеріалу. Так, рослини пшениці озимої, розміщені у посівах по чорному пару більш швидко вступали до фази кущіння. Період «сходи-кущіння» на ділянках досліду, де насіння перед сівбою протруювали «Вітаваксом 200 ФФ», а також на контрольному варіанті становив 17 діб. Обробка зерна мікродобривом «Реаком-плюсзерно» окремо та сумісно з протруйником «Вітавакс 200 ФФ» сприяла більш швидкому розкущенню рослин пшениці. Застосування протруйника «Селест Топ» окремо, а також його сумішкою 3 мікродобривом скорочувало тривалість періоду «сходи-кущіння» на дві доби порівняно 3 контролем. Під час вирощування після гороху та соняшника обробка насіння «Селест Топом» та сумішкою «Селест Топ» + «Реаком-плюсзерно» настання фази кущіння, як і по паровому попереднику, відбувалося на дві доби раніше, ніж на контролі. Більш швидкий розвиток пшениці озимої обумовлений позитивним впливом на ростові процеси рослин протруйника «Селест Топ» та мікродобрива «Реаком-плюс-зерно». Зокрема, це проявилося у формуванні більшої кущистості у сортів пшениці озимої на цих варіантах.

Кількість сформованих пагонів кущення за осінній період вегетації визначалась сортовими особливостями рослин залежала від попередників та передпосівної обробки насіння. В середньому за роки досліджень, у випадку вирощування по чорному пару, найбільшою кущистістю відзначався сорт Скарбниця, рослини якого формували більшу кількість пагонів, порівняно із сортами Писанка і Апогей Луганський. Залежно від передпосівної обробки насіння у вказаних сортів вона знаходилась у межах 4,6-5,4; 4,4-5,2 та 4,2-5,0 шт./рослину відповідно. У разі виро- щування після гороху та соняшника більшою кущистістю на час припинення осінньої вегетації характеризувалися рослини сорту Писанка. По зазначених попередниках вона становила відповідно 3,9-4,7 та 3,5-4,3 шт./рослину. У сортів Скарбниця та Апогей Луганський коефіцієнт кущення становив 3,8-4,6; 3,7-4,6 та 3,5-4,3; 3,3-4,1 шт./рослину відповідно. Максимальну кущистість рослини пшениці формували на варіантах досліду, які передбачали передпосівну обробку насіння сумішкою протруйника «Селест Топ», який використовували повною і зменшеною дозою, сумісно 3 мікродобривом «Реаком-плюсзерно». Порівняно з контролем, різниця у кущистості в сортів Писанка, Скарбниця та Апогей Луганський під час вирощування по чорному пару становила 15,$4 ; 14,8 ; 16,0 \%$, після гороху і соняшника $-17,0 ; 17,4 ; 19,6 \%$ та 18,$6 ; 18,6 ; 19,5 \%$ відповідно (табл. 4). Рослини пшениці озимої, на варіантах досліду, що передбачали сумісне застосування Селест Топу (повна і зменшена доза) та Реакому-плюс-зерно, сформували максимальну кількість вузлових коренів. Так, на зазначених ділянках, у разі вирощування озимини після соняшника даний показник у сорту Писанка дорівнював 4,6 шт./рослину, в сортів Скарбниця та Апогей Луганський - 4,5 шт./ рослину. За сівби після гороху відповідно до вказаних сортів - 5,3; 5,2 та 4,9 шт./рослину. По чорному пару рослини мали найбільшу кількість вузлових коренів, яка у сорту Скарбниця була найвищою i становила 6,1 шт./рослину, у сортів Скарбниця та Апогей Луганський - 6,2 та 5,8 шт./рослину відповідно. За результатами досліджень встановлено вплив умов вирощування на кількість нагромадженої рослинами надземної маси за осінній період вегетації. На час припинення осінньої вегетації більшу масу 100 абсолютно сухих рослин формували посіви пшениці озимої, розміщені по чорному пару. Найвищою серед сортів вона була у сорту Скарбниця i, залежно від обробки насіння, даний показник знаходився в межах 40,6-43,4 г, в сорту Апогей Луганський - 40,8-42,9 г, в сорту Писанка - 39,8-41,9 г.

На час припинення осінньої вегетації максимальну масу 100 абсолютно сухих рослин усі сорти пшениці озимої формували на варіантах досліду, які передбачали сумісне застосування протруйника «Селест Топ» та мікродобрива «Реаком-плюс-зерно». В середньому за 2009-2011 pр. у сортів Писанка, Скарбниця та Апогей Луганський на зазначених ділянках по чорному пару вона становила відповідно 41,9; 43,4 та 42,9 г. У випадку вирощування після гороху маса рослин, порівняно з чорним паром, була на 11,$9 ; 12,7$ та $11,0 \%$ нижчою, після соняшника на 17,$7 ; 21,9$ та 21,2 \% відповідно (табл. 5). 


\section{4. Формування пагонів кущення (ит./рослину) рослинами різних сортів пшениці озимої на час припинення осінньої вететації залежно від умов вирощування, (середнс за 2009-2011 рр.)}

\begin{tabular}{|c|c|c|c|}
\hline \multirow{2}{*}{ Обробка насіння } & \multicolumn{3}{|c|}{ Попередники } \\
\hline & чорний пар & горох & соняшник \\
\hline \multicolumn{4}{|l|}{ Сорт Писанка } \\
\hline Контроль (без обробки) & 4,4 & 3,9 & 3,5 \\
\hline «Вітавакс 200 ФФ» & 4,5 & 4,0 & 3,6 \\
\hline «Реаком-плюс-зерно» & 4,8 & 4,3 & 3,9 \\
\hline «Вітавакс 200 ФФ» + «Реаком-плюс-зерно» & 4,8 & 4,3 & 3,9 \\
\hline «Вітавакс 200 ФФ» (70 \% норми) + «Реаком-плюс-зерно» & 4,8 & 4,3 & 3,9 \\
\hline «Селест Топ» & 5,0 & 4,5 & 4,1 \\
\hline «Селест Топ» + «Реаком-плюс-зерно» & 5,2 & 4,7 & 4,3 \\
\hline «Селест Топ» $(70$ \% норми) + «Реаком-плюс-зерно» & 5,2 & 4,7 & 4,3 \\
\hline \multicolumn{4}{|l|}{ Сорт Скарбниця } \\
\hline Контроль (без обробки) & 4,6 & 3,8 & 3,5 \\
\hline «Вітавакс $200 \Phi \Phi »$ & 4,7 & 3,9 & 3,6 \\
\hline «Реаком-плюс-зерно» & 5,0 & 4,2 & 3,9 \\
\hline «Вітавакс $200 \Phi Ф »+$ «Реаком-плюс-зерно» & 5,0 & 4,2 & 3,9 \\
\hline «Вітавакс 200 ФФ» $(70$ \% норми $)+$ «Реаком-плюс-зерно» & 5,0 & 4,2 & 3,9 \\
\hline «Селест Топ» & 5,2 & 4,4 & 4,1 \\
\hline «Селест Топ» + «Реаком-плюс-зерно» & 5,4 & 4,6 & 4,3 \\
\hline «Селест Топ» $(70$ \% норми $)+$ «Реаком-плюс-зерно» & 5,4 & 4,6 & 4,3 \\
\hline \multicolumn{4}{|l|}{ Сорт Апогей Луганський } \\
\hline Контроль (без обробки) & 4,2 & 3,7 & 3,3 \\
\hline «Вітавакс $200 \Phi \Phi »$ & 4,3 & 3,9 & 3,4 \\
\hline «Реаком-плюс-зерно» & 4,6 & 4,2 & 3,7 \\
\hline «Вітавакс 200 ФФ» + «Реаком-плюс-зерно» & 4,7 & 4,2 & 3,7 \\
\hline «Вітавакс 200 ФФ» $(70$ \% норми $)+$ «Реаком-плюс-зерно» & 4,6 & 4,2 & 3,7 \\
\hline «Селест Топ» & 4,8 & 4,4 & 3,9 \\
\hline «Селест Топ» + «Реаком-плюс-зерно» & 5,0 & 4,6 & 4,1 \\
\hline «Селест Топ» $(70$ \% норми) + «Реаком-плюс-зерно» & 5,0 & 4,6 & 4,1 \\
\hline
\end{tabular}

Мінімальну масу 100 абсолютно сухих рослин відмічали на варіантах досліду, де сівбу проводили нічим не обробленим насінням.

Так, під час вирощування після соняшника цей показник становив у сорту Писанка - 32,0 г, у сортів Скарбниця та Апогей Луганський - 31,8 та 31,6 г. відповідно. За сівби після гороху маса рослин становила 34,$8 ; 34,3 ; 35,9$ г, по чорному пару - 39,8; 40,6 та 40,8 г відповідно.

Експериментально доведено, що під час вирощування по чорному пару найвищу врожай- ність сорти Скарбниця (6,69 т/га), Писанка (6,40 т/га) та Апогей Луганський (6,20 т/га) формували на варіантах досліду, які передбачали проведення передпосівної обробки насіння протруйником «Селест Топ 312.5 FS» (1,5 л/т) та мікродобривом «Реаком-плюс-зерно».

Під час вирощування пшениці після соняшника та гороху урожайність зазначених сортів на цих варіантах становила 3,$50 ; 3,74 ; 3,42$ та 4,13; 4,43; 3,94 т/га відповідно. 
СТОРІНКА МОЛОДОГО ВЧЕНОГО

5. Формування абсолютно сухої маси 100 рослин пщениці озимої (2) на час припинення осінньої вететації залежно від умов вирощування, (середнс за 2009-2011 рр.)

\begin{tabular}{|c|c|c|c|}
\hline \multirow{2}{*}{ Обробка насіння } & \multicolumn{3}{|c|}{ Попередники } \\
\hline & чорний пар & горох & соняшник \\
\hline \multicolumn{4}{|l|}{ Сорт Писанка } \\
\hline Контроль (без обробки) & 39,8 & 34,8 & 32,0 \\
\hline «Вітавакс 200 ФФ» & 40,0 & 34,9 & 32,5 \\
\hline «Реаком-плюс-зерно» & 40,7 & 35,8 & 33,4 \\
\hline «Вітавакс 200 ФФ» + «Реаком-плюс-зерно» & 41,1 & 36,9 & 33,8 \\
\hline «Вітавакс 200 ФФ» $(70$ \% норми $)+$ «Реаком-плюс-зерно» & 41,0 & 41,0 & 33,6 \\
\hline «Селест Топ» & 40,7 & 35,7 & 33,5 \\
\hline «Селест Топ» + «Реаком-плюс-зерно» & 41,9 & 36,9 & 34,5 \\
\hline «Селест Топ» $(70$ \% норми $)+$ «Реаком-плюс-зерно» & 41,8 & 36,8 & 34,2 \\
\hline \multicolumn{4}{|l|}{ Сорт Скарбниця } \\
\hline Контроль (без обробки) & 40,6 & 34,3 & 31,8 \\
\hline «Вітавакс 200 ФФ» & 41,0 & 34,5 & 32,0 \\
\hline «Реаком-плюс-зерно» & 41,7 & 35,3 & 32,8 \\
\hline «Вітавакс $200 \Phi \Phi »+$ «Реаком-плюс-зерно» & 42,0 & 37,3 & 33,4 \\
\hline «Вітавакс 200 ФФ» $(70$ \% норми $)+$ «Реаком-плюс-зерно» & 41,9 & 36,1 & 33,7 \\
\hline «Селест Топ» & 41,7 & 36,2 & 33,0 \\
\hline «Селест Топ» + «Реаком-плюс-зерно» & 43,4 & 37,9 & 33,9 \\
\hline «Селест Топ» $(70$ \% норми $)+$ «Реаком-плюс-зерно» & 43,2 & 37,7 & 33,8 \\
\hline \multicolumn{4}{|l|}{ Сорт Апогей Луганський } \\
\hline Контроль (без обробки) & 40,8 & 35,9 & 31,6 \\
\hline «Вітавакс $200 \Phi \Phi »$ & 40,9 & 35,9 & 31,8 \\
\hline «Реаком-плюс-зерно» & 41,5 & 36,7 & 32,9 \\
\hline «Вітавакс 200 ФФ» + «Реаком-плюс-зерно» & 42,4 & 37,4 & 33,4 \\
\hline «Вітавакс 200 ФФ» $(70$ \% норми $)+$ «Реаком-плюс-зерно» & 42,5 & 37,5 & 33,4 \\
\hline «Селест Топ» & 41,9 & 36,8 & 33,0 \\
\hline «Селест Топ» + «Реаком-плюс-зерно» & 42,9 & 38,2 & 33,8 \\
\hline «Селест Топ» $(70 \%$ норми $)+$ «Реаком-плюс-зерно» & 42,8 & 37,8 & 33,7 \\
\hline
\end{tabular}

Висновки. За період осінньої вегетації максимальні значення коефіцієнта кущення відмічали на варіантах досліду, які передбачали передпосівну обробку насіння препаратом «Селест Топ 312.5 FS», який використовували повною і зменшеною дозою сумісно з мікродобривом «Реакомплюс-зерно».

Порівняно з контролем, різниця в кущистості у сортів Писанка, Скарбниця та Апогей Луганський у випадку вирощування по чорному пару становила 15,$4 ; 14,8 ; 16,0 \%$, після гороху і соняшника - 17,0; 17,$4 ; 19,6 \%$ та 18,$6 ; 18,6 ; 19,5 \%$ відповідно. Польова схожість та маса 100 абсолютно сухих рослин також були найвищими на цих варіантах досліду. В середньому за роки досліджень найвищу врожайність забезпечувала передпосівна обробка насіння протруйником «Селест Топ 312.5 FS» (1,5 л/т) та мікродобри- вом «Реаком-плюс-зерно». Під час вирощування по чорному пару в сорту Писанка вона становила 6,40 т/га, в сорту Скарбниця - 6,69 т/га, в сорту Апогей Луганський - 6,20 т/га.

За розміщення вказаних сортів після соняшника та гороху урожайність зерна становила 3,74; 3,50; 3,42 т/га та 4,43; 4,13; 3,94 т/га відповідно.

Одержані результати досліджень сприяють розробці науково-обгрунтованих рекомендацій 3 вирощування пшениці озимої після гороху i соняшника, а також по чорному пару в умовах північного Степу України, що дасть змогу суттєво збільшити валові збори якісного зерна в регіоні. Результати досліджень поповнили наукову базу даних i будуть використані в подальших дослідженнях. 


\section{БІБЛІОГРАФІЯ}

1. Азов С. А. Влияние протравливания на всхожесть травмированных семян / С. А. Азов // Защита растений. - К., 2005. - С. 55-60.

2. Борчук И. Протравливать или нет, если да то чем? // Зерно. Всеукраинский журнал современного агропромышленника. - К., 2009. - №7 (39). C. $96-98$.

3. Доспехов Б. А. Методика опытного дела / Б. А. Доспехов. - М. : Колос, 1985. - 336 с.

4. Еще раз о важности протравливания семян // Зерновые культуры. - М., 1999. - №2. - С. 27-30.

5. Желязков $O$. I. Вплив агротехнічних прийомів вирощування на зернову продуктивність пшениці озимої по стерньовому попереднику / О. I. Желязков // Бюлетень Інституту сільського господарства степової зони НААН України. - Д. : «Нова ідеологія», 2014. - №7. - С. 133-139.

6. Кавунеи В. П. Эффективность протравливания травмированных семян озимой пшеницы / В. П. Кавунец, В. Я. Дворник, В. И. Шелепова // Селекция и семеноводство. - К., 1990. - №1. C. $39-41$.
7. Ковалишина Г. М. Що впливає на схожість насіння / Г. М. Ковалишина // Карантин і захист рослин. - 2004. - №8. - С. 1-3.

8. Методические рекомендации по проведению полевых опытов с зерновыми, зернобобовыми и кормовыми культурами / [под ред. В. С. Цыкова и Г. Р. Пикуша]. - Днепропетровск, 1983. $46 \mathrm{c}$.

9. Методика державного сортовипробування с.-г. культур / [за ред. В. В. Вовкодава]. - К., 2001. Вип. 2. $-65 \mathrm{c}$.

10. Фатеев А. И. Влияние микроудобрений «Реаком» на засухо- и морозостойкость растений, их устойчивость к болезням / А. И. Фатеев, С. П. Полянчиков // Агроном. - 2010. - №4. C. 32-35.

11. Ярошенко С. С. Вплив протруйників насіння на продуктивність пшениці озимої / С. С. Ярошенко // Бюлетень Інституту сільського господарства степової зони НААН України. - Дніпропетровськ, 2012. - №2. - С. 137-139. 